\title{
Britain in Decline
}


Also by Andrew Gamble

From Alienation to Surplus Value (with Paul Walton)

The Conservative Nation.

Capitalism in Crisis (with Paul Walton)

An Introduction to Modern Social and Political Thought

The British Party System and Economic Policy 1945-83

(with Stuart Walkland)

The Free Economy and the Strong State

Developments in British Politics 4 (co-editor) 


\section{Britain in Decline}

Economic Policy, Political Strategy and the British State

FOURTH EDITION

Andrew Gamble

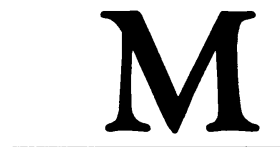

St. Martin's Press 
All rights reserved. No reproduction, copy or transmission of this publication may be made without written permission.

No paragraph of this publication may be reproduced, copied or transmitted save with written permission or in accordance with the provisions of the Copyright, Designs and Patents Act 1988, or under the terms of any licence permitting limited copying issued by the Copyright Licensing Agency, 90 Tottenham Court Road, London WIP 9HE.

Any person who does any unauthorised act in relation to this publication may be liable to criminal prosecution and civil claims for damages.

Published in Great Britain by THE MACMILLAN PRESS LTD

Houndmills, Basingstoke, Hampshire RG21 2XS

and London

Companies and representatives

throughout the world

A catalogue record for this book is available from the British Library.

ISBN 978-0-333-61441-9

DOI 10.1007/978-1-349-23620-6

First edition 1981

Reprinted 1983, 1984

Second edition 1985

Reprinted 1986, 1988, 1989

Third edition 1990

Reprinted 1991, 1992, 1993

Fourth edition 1994

Published in the United States of America by

Scholarly and Reference Division,

ST. MARTIN'S PRESS, INC.,

175 Fifth Avenue,

New York, N.Y. 10010

ISBN 978-0-312-12239-3

Library of Congress Cataloging-in-Publication Data

Gamble, Andrew.

Britain in decline : economic policy, political strategy, and the British state / Andrew Gamble. - 4th ed.

p. $\mathbf{c m}$.

Includes bibliographical references and index.

ISBN 0-312-12239-X

1. Great Britain-Economic policy-1945- 2. Great Britain-Politics and government-1945- I. Title.

HC256.6.G35 1994

$338.941-\mathrm{dc} 20$ 
In memory of A. N. Silver 
The purely British causes of the economic depression are complex, but they can be summed up in a single sentence. English manufacturing costs are among the highest in the world. If this situation continues, any economic structure based on exports is faced with inevitable ruin ... England is trying to compete in international markets, and at the same time provide her people with a wage level and a standard of living which does not permit costs to be low enough either to export profitably, or to attract the capital necessary for the development and upkeep of her manufacturing.

André Siegfried, England's Crisis (1931)

What with our sentimentality, our Party system, our government by committee, our 'Mandarins', our 'Society', and our Generals ... the game is just hopeless ... Our political organisation is thoroughly rotten, almost non-existent. It is Carthaginian - really the only comparison I can think of. Never was there such an absurd waste of power, such ridiculous inconsequence of policy - not for want of men but for want of any effective central authority or dominant idea to make them work together.

Lord Milner (1909)

Shame is a kind of anger turned in on itself. And if a whole nation were to feel ashamed it would be like a lion recoiling in order to spring. I admit that even this shame is not yet to be found in Germany; on the contrary the wretches are still patriots. But if the ridiculous system of our new knight does not disabuse them of their patriotism, then what will? ... The state is too serious a business to be subjected to such buffoonery. A Ship of Fools can perhaps be allowed to drift before the wind for a good while; but it will still drift to its doom precisely because the fools refuse to believe it possible. This doom is the approaching revolution.

Karl Marx (1843) 


\section{Contents}

Acknowledgements

Preface

$\mathrm{x}$

Introduction

PART I DECI.INE

1. The hundred years' decline 3

1.1 Britain and the world economy 4

1.2 The long boom 6

1.3 The measurement of decline 10

$\begin{array}{ll}1.4 \text { The debates of the intellectuals } & 18\end{array}$

(i) The debate on policy 18

(ii) The historical debates $\quad 26$

(iii) Four theses on decline $\quad 30$

1.5 Conclusion $\quad 38$

PART II HISTORY

2. The world island 43

2.1 The expansion of England 43

2.2 The drive to empire 47

2.3 Industrialisation and free trade $\quad 50$

2.4 The beginnings of decline 53

2.5 Britain and the world economy 58

3. The unfinished revolution 64

3.1 The state and civil society 65

3.2 The English governing class 71 
3.3 The resistance of the working class 74

3.4 The response to the working class 78

3.5 Mass democracy and the imperial state 83

3.6 The Labour party and the Constitution 87

PART III STRATEGY

4. Managing social democracy 99

4.1 The triumph of social democracy 100

4.2 Reconstruction $\quad 103$

4.3 The American connection 105

4.4 The burden of the world role 109

4.5 The growing awareness of decline 113

4.6 The attempt at modernisation 118

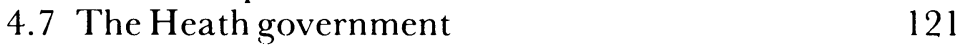

5. The sovereign market 127

5.1 Free trade and sound finance 128

5.2 The New Right 137

5.3 The free economy 143

$\begin{array}{ll}5.4 \text { Monetarism } & 147\end{array}$

5.5 State intervention $\quad 149$

5.6 Trade-union power 151

5.7 Democracy 153

6. The enterprise state 157

6.1 Social Imperialism 158

6.2 Fascism and the slump $\quad 165$

6.3 Labour and the national economy $\quad 168$

6.4 The Left challenge 171

6.5 Regaining national economic sovereignty 174

6.6 The regeneration of British industry 179

6.7 The political problem 181

7. The end of decline? 186

7.1 The Thatcherite project 186

7.2 The market cure 191

7.3 The debate on recovery 201 
Contents ix

7.4 The criteria for success

213

7.5 The future of decline

218

Notes and References

226

Index

254 


\section{Acknowledgements}

The author and publishers wish to thank the following who have kindly given permission for the use of copyright material: Banco Nazionale Del Lavoro for data from an article 'Phases of Capitalist Development' by A. Maddison, published in the June 1977 issue of the Bank's Quarterly Review; The Controller of Her Majesty's Stationery Office for data from Royal Commission on Trade Unions and Employers' Associations, Report and Employment Gazette; National Institute of Economic and Social Research for tables from Review; Organisation for Economic Co-operation and Development for tables from OECD Reports, National Accounts 1961-7 and Economic Outlook, July 1979 and June 1993. 


\section{Preface}

This book was a product of the 1970s and first appeared in 1981 at the beginning of the great economic and political shakeout which accompanied the Thatcher Government's attempt to reverse British decline. The second and third editions were prepared and appeared during the Thatcher era. This fourth edition has been prepared after its end. Much has changed since the book was first written, and my perspective on many of the issues discussed in these pages has changed also. In all the later editions, however, I have kept changes to the main chapters to a minimum, leaving them as a commentary on the debates and the solutions proposed in the 1970s. The main changes over the four editions have been to the Introduction, to Chapter 1 and to the Conclusion. The final chapter has been completely rewritten, and in this fourth edition offers an assessment of the achievements and the significance of the Thatcher Government in the context of the long debate on British decline.

The original title of the book was The Politics of Decline, which in certain respects expresses more accurately the contents and approach of the book. It is a study of how decline has been perceived and the perceptions of decline and of the political struggles to reverse decline, rather than of decline as an external objective process. Whether there has been a decline and whether it can be measured depends on whether there is such an entity as the British national economy. In the era of national protectionism in the world economy which has now ended, the British political elite certainly believed there was such an entity, and perceived Britain to be in decline both as a world power and as a national economy. It is this perception and the historical experience which informs it which is the main subject of this book.

Many people helped me write it. I owe a great deal to 


\section{xii Preface}

students at Sheffield who attended my course on political economy. I also learnt much from discussion with friends and colleagues and I would particularly like to thank Jerry Agnew, Anthony Arblaster, David Baker, Peter Duff, Brian Duncan, Stephen George, Ankie Hoogvelt, Eddie Jachcel, Steve Ludlam, David Marquand, Bryan Mason, Tony Payne, Ben Rosamond, Quentin Rudland, Patrick Seyd, Martin Smith, Ian Taylor and Stuart Walkland.

My wider intellectual debts are too many to mention. They are apparent on every page of this book. Its judgements and arguments lean heavily on the work of others. This book would not have been possible without the pioneering work of Perry Anderson and Tom Nairn in their seminal essay in New Left Review in the 1960s which opened up a new range of questions about the interpretation of English history. Henry Drucker, Martin Jacques and Ralph Miliband encouraged me to develop in essay form some of the ideas explored in this book. Henk Overbeek and Bob Jessop, through their writings on decline, stimulated me to clarify some of my conceptions, as, did two conferences organised by Michael Mann in Cambridge in 1988 and Uffe Ostergaard in Aarhus in 1991.

The book was nursed into life by four Macmillan editors: Shaie Selzer, Rob Shreeve, John Winckler and Steven Kennedy. I owe a great deal in particular to Steven Kennedy for his special and much appreciated assistance and advice. Thanks are also due to Keith Povey, who has been an extremely efficient and helpful copy-editor for all four editions; and to Hazel Watson, who prepared the original typescript. My family gave me great support throughout the writing of this book, as did Neil Lyndon, even if it turned out rather differently from what he expected.

I owe a special debt to Yoshi Ogasawara, who studied with me in Sheffield and undertook the laborious task of translating the book into Japanese. The Japanese take a special interest in the question of Britain's decline, perhaps in the spirit of Marx's advice to the Germans that they heed the lessons of British development - 'De Te Fabula Narratur.' 


\section{Introduction}

It is remarkable to see how relatively numerous in declining empires are the people capable of making the right diagnosis and preaching some sensible cure. It is no less remarkable, however, that wise utterances generally remain sterile, because, as Gonzales de Cellorigo forcefully put it while watching impotently the decline of Spain, 'those who can will not and those who will cannot'.

\section{Carlo Cipolla ${ }^{1}$}

Britain has now been in decline for a hundred years. It has become the most observed and analysed decline in modern history, provoking a speculative literature of enormous dimensions. Few explanations have not been proffered, few causes not dissected, few remedies not canvassed at least twice. The decline has been the central fact about British politics for a century, a major preoccupation of its public intellectuals and intermittently but increasingly of its political leaders. Two processes stand out - the absolute decline in the power and status of the British imperial state, and the relative decline of the British economy with its long-standing failure to match the rates of expansion of its rivals.

The starting point of Britain's decline was the position of unrivalled dominance it had achieved during the nineteenth century. By 1900 Britain controlled over one-fifth of the world's land surface and ruled one-quarter of the world's population. Its land forces remained small but its navy was still maintained at a level where it would be superior to the two next most powerful navies combined. The foundations of this empire had been the commercial and strategic policies pursued by the British state for 250 years. Its consolidation and further extension in the nineteenth century had been the 


\section{xiv Introduction}

result of the industrial and technological lead Britain established by being the first major economy to industrialise. The height of Britain's industrial domination of the world was reached in the middle decades of the nineteenth century. At that time one third of the world's output of manufactured goods came from Britain. Britain produced half the world's coal and iron, half the world's cotton goods, almost half its steel. From this position Britain conducted one-quarter of the world's trade and built up a massive commercial and financial predominance. Even in 1900 Britain still accounted for onethird of the world's exports of manufactures, and the registered tonnage of British shipping was more than the tonnage of the rest of the world combined. London was the unchallenged commercial and financial centre of the new capitalist world economy. The international monetary system was centred upon the gold standard and the pound sterling, and British foreign investments had risen by 1914 to the remarkable total of $£ 4000$ million.

By the last decade of the twentieth century a very different picture presented itself. The British Empire had disappeared. Only a few last outposts such as Hong Kong and the Falkland Islands remained. Britain retained some of the trappings of a great power. It still had a nuclear arsenal, substantial and well-equipped armed forces, and a permanent seat on the UN Security Council. But it was no longer the kind of global power it had been in the first half of the century, and its proud tradition of sovereign independence was increasingly circumscribed by the new realities and requirements of interdependence. The security and economic relationships forged with the United States and Western Europe after 1945 were indications of how limited British sovereignty had become.

The British economy was incomparably richer and more productive in 1990 than in 1900 but it was no longer the world leader or the powerhouse of the world economy. It remained one of the richest economies in the world, but its position and performance relative to other economies in the leading group had substantially weakened. On a range of indicators Britain had slipped behind and despite several determined attempts showed no signs of being able to catch up.

The slope of Britain's descent has not been constant. There 
have been periods of recovery, even of advance and success, but they do not affect the overall judgement that Britain in the twentieth century has been a state in decline and that the efforts of its governing class have failed to arrest that decline. The problems surrounding Britain's future have accumulated while the reserves for meeting them have dwindled.

There is a vast literature on decline but little agreement about how decline should be defined and still less about how it should be explained. This is hardly surprising. Decline is to an important extent a matter of political perception rather than an objective reality. To study decline is to study the perceptions and responses of the British governing class during the last hundred years. For many of them the decline in world power and the relative decline in economic performance are inextricably linked. They are part of the same process.

The crucial contexts which have shaped the domestic debates on decline and what to do about it have been formed by Britain's changing place in the world order. There have been three key debates, which are examined in this book - the debate on National Efficiency before 1914; the debate on modernisation from the 1920s through to the 1960s; and the debate on social democracy from the 1960s through to the present. These debates succeed one another chronologically, although they also overlap, and arguments and positions from the earlier debates often reappear in the later ones.

One of the most persistent aspects of the discourse on decline is the belief in a 'British disease', a malady whose causes lie deep in British psychology and British culture. A popular diagnosis of this 'disease' in the 1960s and 1970s was that the country was living beyond its means. The British consumed too much and worked too little. As one Labour minister memorably put it: 'For generations this country has not earned an honest living'. ${ }^{2}$

What made such assertions plausible were repeated economic crises - over the balance of payments, ${ }^{3}$ public expenditure, and pay. The nation it was said was importing more than it exported, the government was spending more than it raised in taxes, and the workers were demanding the distribution of a bigger cake than the one they were producing. The con- 


\section{xvi Introduction}

sequences of such behaviour was placing Britain's future prosperity and its traditional freedoms in danger.

The favourite political scapegoat for the British disease used to be the trade unions. Their behaviour was most frequently cited as the reason why Britain's payments would not balance, why public expenditure was out of control and was beginning to encroach on 'our plural society', ${ }^{4}$ and why inflation was accelerating. ${ }^{5}$ Sir Keith Joseph summed up twenty years of anti-union criticism in the title of a speech delivered in 1979 during the Winter of Discontent: 'Solving the trade union problem is the key to Britain's economic recovery. ${ }^{6}$

When Margaret Thatcher left office in 1990 trade unions had been weakened by a decade of high unemployment and anti-union legislation. The Government claimed the change in the climate of industrial relations as one of their greatest successes. Management had regained the power to manage. But the symptoms of the British disease appeared little affected. The public finances and the balance of payments were once again out of control and heading for record deficits. Inflation was rising sharply and the economy was moving back into recession. Solving the trade union problem, it seems, was not enough.

Many writers on decline had never thought it was. Some have attempted to explain Britain's post-war failure in terms of the cyclical patterns at work in the history of all great empires. Parallels for Britain's experience have been sought in the declines of other great imperial powers - Rome, Venice, Spain. As in other small states which have created empires the qualities and attitudes which assisted Britain to rise and expand were discarded or neglected by the later generations which inherited the imperial position. They developed instead tastes, needs, and activities which were sustainable only so long as Britain retained its economic and military leadership, yet which tended to undermine the basis of that strength. Britain's rise to world power was followed by the development of a pervasive 'anti-enterprise' culture and a social conservatism at all levels, particularly in education and business management, which persistently blocked successful modernisation and adaptation. 
Trade unions are part of this 'anti-enterprise culture' but not the only or the most important part. The real source of Britain's decline is traced to the attitudes and the behaviour of political elites. ${ }^{7}$ Such is the argument of two of the most influential books published on British decline in recent years Corelli Barnett's The Audit of War and Martin Wiener's English Culture and the Decline of the Industrial Spirit, 1870-1980. Both were cited by Thatcherite ministers as evidence that Britain required a radical change in the climate of ideas, a cultural revolution, to rebuild a vibrant capitalist economy.

Barnett argued in his study of the shortcomings of British industry in the second world war that the problems of poor management, overmanning, restrictive practices, low investment, and low productivity were rife throughout British industry even during the war-time economy, which according to official accounts had been one time when the British economy had performed well. Barnett argued that the euphoria of victory allowed these failings to be ignored. Postwar reconstruction was fatally flawed by being directed on the one hand to the building of a universal welfare state, a New Jerusalem, a project which had come to dominate the thinking of the bulk of the British political elite, and on the other hand to the preservation of Britain's world role. Both New Jerusalem and the world role assumed a strong economy which no longer existed. Their spending programmes were therefore erected on very shaky foundations.

Critics of this cultural or 'declinist' thesis have argued that the evidence for it is highly selective; that the whole notion of decline is an illusion; and that it has often been used as a way of justifying technocratic and authoritarian policy solutions. ${ }^{8}$ The standpoint of this book is rather different. The cultural thesis often presents an exaggerated and misleading picture of the British economy and its performance, but its critics are sometimes in danger of asserting the contrary - that there has been no decline at all, and that all the problems dealt with as problems of decline are no more than normal problems of change and adjustment. This book analyses decline in two main ways: first as a discourse which was constituted by the particular ideas and assumptions of those participating in it; secondly as a historical process, a set of circumstances and 
constraints which defined the limits within which the debate proceeded.

Understanding British decline as a historical process requires analysis of the complex interplay between the decline in British power and the decline in British competitiveness. What was different about Britain's Empire compared with the great empires of the past was that it became inextricably linked with a global process of capital accumulation which resulted in the creation of an interdependent world economy and a rate of growth of population and material wealth far surpassing any levels previously achieved in human history. ${ }^{9}$

Britain's expansion may have been launched upon foundations that were similar to those of many previous empires, but it reached its zenith and was consolidated under very different ones. When earlier empires that arose from a self-sufficient agricultural base collapsed, the imperial state was forced back to this base, once decline had reached a certain point. That possibility disappeared for Britain during the nineteenth century. At a certain stage of its development Britain abandoned such foundations, merging its future irrevocably with the wider world economy.

All discussion of British decline must start from Britain's relationship to the world economy that was the means of Britain's rise, which was transformed in the course of that rise, and to which Britain remains tied. What has to be explained is why the most dynamic and expansionist nation in modern European history, the organiser of the largest world empire, the pioneer of industrialisation, and the country renowned above all others for continuity of its institutions and the political skill of its ruling class, should have lost out during the last thirty years in competition with Germany, France, and Japan. The eclipse of British military power by the United States and Russia was widely forecast as early as the 1840 s because of the much greater human and physical resources they could command. What was not anticipated was the relative inability of the British economy to maintain its dynamism and compete with its rivals.

A central problem for British historiography in the twentieth century has been why the British economy proved so weak and why political attempts to overcome this weakness were 
not successful. The unevenness of the development of different economies and regions within the world economy has been a noted feature of the modern era. Recognition of backwardness has acted as a spur for states to modernise themselves and catch up with the economic leaders. According to this argument the disappearance of Britain's lead over its competitors was entirely predictable. What is not so easily explained is the feebleness of the British response. Charles Feinstein has argued that 'the leader who falls behind will ultimately respond to the changed circumstances and in particular to the increased threat to markets and jobs created by the formerly backward economies. ' ${ }^{10}$ Yet although Britain had clearly lost its economic leadership to the United States by 1914 , and had fallen behind other competitors in the 1950s and 1960s the response was a very long time in coming.

One explanation is that for most of the period of its decline the British state has proved able to negotiate a gradual descent. At no point did failing power threaten a major rupture in institutional continuity or an irreversible collapse of British prosperity. The decline in the world power of the British state occurred in stages. The continuing expansion of the British economy helped to compensate for that decline and to limit its impact. The British state used its considerable political, idcological, economic and financial resources, which had been accumulated during the period of British dominance of the world economy, to buy time, to stave off challenges and to delay adjustments. When crises shook the world economy, the British state and the British economy were strong enough to ride them out. But this success reduced the will to tackle many internal weaknesses which gradually became more significant as Britain's relative position deteriorated.

During the world economic downturn in the 1970s, the relative weakness of the British economy, tolerated for so long, became increasingly unsupportable, and brought growing political and social tensions. The world recession changed the political climate by threatening to turn relative decline into absolute decline. Some observers argued that there was no general crisis of capitalism, only a crisis of capitalism in Britain. But general crises always take the form of national crises, and their impact is uneven depending on the ability of 
each state to protect itself, drawing on whatever resources and strengths it has. The consequences of a recession like the consequences of a boom are unevenly distributed because the world economy is an interdependent economic system rather than a group of self-contained national economies. To analyse the economic policy of a nation-state like Britain it is important to place Britain in the context of the wider world system.

In the 1970s Britain came to be widely perceived as a weak link among the leading economic powers. The worries about the balance of payments, inflation, and public spending were symptoms of wider anxieties about Britain's economic future, because of the apparently unstoppable tide of imports and the inability of so many sectors of British industry to compete. The extent of the shakeout which took place in the 1970s and 1980s prompted many people to ask how much further the contraction could go. What would be the end of it? A Britain with no industry at all? Unemployment and destitution of an unimaginable scale? Exports insufficient even to pay for the imports needed to feed the population? The fears were not new. Joseph Chamberlain, Radical, Imperialist, and Tariff Reformer, declared in 1903: ${ }^{11}$

Agriculture, as the greatest of all trades and industries of this country, has been practically destroyed. Sugar has gone; silk has gone; iron is threatened; wool is threatened; cotton will go! How long are you going to stand it?

Many found it difficult to comprehend how a nation that was on the winning side in two world wars could lose the peace and succumb to the commercial challenge of rivals defeated on the battlefield. How could a nation that showed such unity in the Second World War, and was so long renowned for its traditions of civility and consensus, appear to disunited and racked by conflict, envy, and cynicism in the 1960s and 1970s? Why was Britain, unable to achieve an economic miracle in the 1950 s, still unable to achieve one in the 1960s when so many faults had been identified and so many remedies proposed, and when, for a time, all parties and all major interests subscribed to growth and a strategy for modernising the British economy? 
What we call decline is a product of political perception and definition. The ways in which it is explained are often not independent of the political remedies proposed to deal with it. This book is about the various ways in which decline has been defined and explained, and the political strategies that have emerged to tackle it. It offers an account of Britain's historical development not as a unique self-contained experience but as the interaction between the external expansion of the state and the internal formation of its principal classes and institutions. Only if Britain is viewed as part of the world economic and political system can the national aspects of British development be properly located. Without a world system perspective the real 'peculiarities' of British development are lost to view. ${ }^{12}$

This book is divided into three parts. Part I explores the concept of decline, examines how it might be measured, and discusses how it has been perceived in the major intellectual debates. Part II discusses the specific historical roots of decline; the history of the British state and the dominant patterns of external expansion and internal compromise; and the history of the working class.

Part III explores three perspectives - market, state, and class - which have dominated debates on decline and which have helped to form political strategies and programmes for overcoming it. Chapter 4 considers the modernisation programmes of the 1960s and 1970s. Chapters 5 and 6 look at the new strategies which emerged in the 1970s in response to the apparent failure of modernisation, the free market strategy of the right and the alternative economic strategy of the left.

The term 'strategy' is here used to mean a discourse on economic policy and political action which is unified and bounded by certain shared assumptions about the desirable relationship between the state and the economy. It identifies long-term objectives and means of achieving them. A strategy in this sense is different from the political programme of a particular party, although it may influence it.

The final chapter assesses whether the Thatcher era is best understood as the long-awaited political response which restructured the economy and brought the decline to an end, or as merely the latest episode in that decline. 